\title{
Icarus and ME: a Fable for 2016
}

In recounting the ancient tale of the fall and death of Icarus, Ovid adds a telling detail. When Icarus and his father Daedalus were flying in the air, they may have been noticed by an angler, a shepherd and a ploughman. As the ill-fated pair flew past, the peasants 'stood stock still in astonishment, believing that these creatures who could fly through the air must be gods'.

In the 1558 Pieter Breugel, who clearly knew his Ovid, painted his great canvas 'Landscape with the Fall of Icarus', in which he depicts the angler, the shepherd and the ploughman. But, far from standing still in astonishment the three peasants are concentrating on their labours. It is not clear that they have even noticed the doomed Icarus. We see only a tiny leg frantically waving in the middle distance, with the rest of his body already sunk in the sea. Indeed most people who see the painting are at first puzzled by its title. Where, they wonder, is Icarus?

'About suffering they were never wrong, / The Old Masters', wrote W.H. Auden in the 1930s, about the Breugel painting. Icarus is indeed the smallest part of the painting. Even if they notice Icarus's desperate plight, everyone present 'turns away quite leisurely from the disaster; the ploughman may/ Have heard the splash, the forsaken cry,/ But for him it was not an important failure.' Life must go on, as, perhaps it did for Auden himself, in self-imposed exile in the United States in the Second World War, and no doubt as it does for most of us, most of the time, despite the disaster and the evil and the 'unimportant' failures all around.

In 2016 Icarus falls from the sky once more. (It is, after all, a perennial event.) Crowds gather round, not with ploughs or sheep or fishing rods. All that stopped a long time ago. Nor is there talk of gods. Armed with their mobiles, people are taking selfies, and even now uploading them on to social media sites. It is 'Icarus and ME'; that is what is important.

(With thanks to Alix Harmer.) 